DOI: $10.20472 /$ IAC.2018.036.020

FATMEH JA'FAR

Amman Arab University, Jordan

\title{
SHATHA AL-AJEELY
}

Amman Arab University, Iraq

\section{CULTURAL DIVERSITY VALUES EMBEDDED IN CHILDREN'S LITERATURE}

\begin{abstract}
:
This study investigated the cultural diversity values embedded in children's stories of the age 8-12 years in the Arab World presented by the characters of the stories, taking Jordan as a case study. The following questions were raised: 1- What are the cultural diversity values embedded in children stories for the age of 8-12 years? 2- What are the characters in children stories in terms of gender (male - female), age (child-adult-old), and types (human-animal) that represented these values? Thirty three stories were chosen and analyzed using a developed checklist of the cultural diversity values, and Child, Potter \& Levine (1971) classification of characters. Findings revealed that the cultural diversity values in children's stories were not sufficient as they should be according to the used scale.
\end{abstract}

\section{Keywords:}

Cultural diversity, values, children's literature.

JEL Classification: A29, 129, Z19 


\section{Introduction}

Since the minute of birth, the baby is exposed to social effects around it, and the permanent interaction with members of the family and the house hold forms the basic mattress for social growth. The family and the household represent a microform of the whole community that embraces many other families and households that are interchangeably affected by the prevailing culture. Culture is the property that characterizes each community with its special features that distinguishes it from other societies, regardless of the level of its development. These exclusive traits of each culture lead to diversity of cultures and societies.

Many educators, anthropologists, socio-psychologists and psychiatrists studied the impact of culture on the character of the individual within a certain culture, and found out that culture has a significant influence on the individual's character and behavior. As we all are subject to this influence, the process itself seems very natural (Pervin, 1990). Kluckhohn (1967) believes that the impact of any process becomes unnoticeable when it turns to be general and inclusive, but its impact appears strong and effective when it is obscured from playing its role. This applies to the culture of the community; its impression on the child is invisible unless he/she is raised in isolation from the human community since birth, he/she will never be more than a creature not different from the rest of animals, if destined to live. He asserts that the importance of the role of culture appears in transforming the human being from a biological to a social creature. As culture is one of the important factors affecting individuals' personalities, it includes patterns of apparent behavior practiced by individuals in the same community and related aspects of their daily lives.

In order for the community to ensure its continuity and evolution, Allport (1983) sees that it resorts to transfer its culture to the next generation through socializing, which is a process of preparing the individual to play a role in the community in which he lives, through acceptable behavior according to the community standards. The constant pressure from the cultural model prevails in society through socialization, the common characteristics that pervade among its members is called "the basic personal spectrum of society".

According to Salvin (2009), the experiences the individual goes through in the first years of his life have an on-going impact on his character, and the socialization tactics employed by members in a society tend to be similar but vary from one community to another. These issues lead to similarities of characteristics and personality traits of members of the same society that distinguish them from members of other communities. Al-Hadidi, (2010) defines culture as a complex and stable mental composite residing in the minds and feelings of our children. It contains beliefs, ideas, knowledge, values, 
attitudes and trends reflected in the behavioral process of mental, artistic and technical skills with results of the achievements of these skills.

In spite of the privacy of the culture of each community, different ethnic groups often integrate in the framework of a single national culture as a result of linguistic and social uniform, showing cultural diversity in a society. Cultural diversity creates a driving force for development, not only on the level of economic growth, but also as means to live an intellectual, emotional, moral and spiritual life in a more comprehensive way, as stipulated in the seven cultural agreements that provide a solid foundation for enhancing cultural diversity. For this, cultural diversity is considered a necessary feature to curb intellectual relentless and achieve sustainable development, also contributes to acceptance of cultural diversity and recognition of the other through the media and information technology and communications, creating dialogue among civilizations and cultures, and the achievement of mutual understanding and respect.

The universal declaration of UNESCO on Cultural Diversity in 2001 and the resulting dialogues, have turned the cultural diversity enhancement and the common heritage of mankind to one of the most pressing contemporary issues, as a core issue for the organization's mandate. Cultural diversity is necessary for humankind the same as the need for biological diversity of living organisms. In this sense and as stated in the Universal Declaration of UNESCO, it is the common heritage of humanity that should be recognized and emphasized for the benefit of present and future generations. Since studies showed that three-quarters of the major conflicts in the world are of cultural dimensions, it is an urgent and important issue to bridge the gap between cultures in order to establish peace, stability and development.

Humanity is not only a group of individuals, nor just a logical abstraction; it is ideals and supreme values which combine analogues together apart from the spatial and temporal boundaries, such as race, religion and skin color. Culture is at the end what people value, therefore it should be given the right attention and respect for human dignity to allow the spread of peace, progress and tolerance among people.

Arabic culture is the product of other cultures stretching from Africa to China, and Central Asia to the Atlantic Ocean. The contribution of different nations and scientists from all these areas enriched its context forming this positive diversity. Arabic culture has gained various tributaries and seemed more diverse; a distinctive feature not available for any other culture. For the importance of the subject, Jordan Club organized a seminar entitled (Amman and cultural diversity), and called the public and private institutions involved in cultural issues to give adequate attention to the development and diversity of events, with the active participation of all Jordanian society fabric components. It is worth mentioning the outstanding interest of cultural diversity in Jordan through conferences held by forums and clubs, and the interest of writers, poets, artists and Association of 
Fine Artists through the slogans raised by them (Amman-The Gate of Cultures). Intellectuals have raised the issues related to cultural diversity domains in the Jordanian society showing the human traits of coalition, love and harmony displayed by its members. For the importance of the subject, a special day was appointed (World Day of Cultural Diversity for Dialogue and Development).

Although the family is one of the most important institutions in the process of cultural transmission to the new generation, Al-Ajili (1979) says that there are other social institutions that play their roles in this process, employing direct and indirect methods in providing social, moral and emotional behavior. In this regard, Qasim (2013) mentions stories as one of the means adopted by a family to transfer values, needs, hopes and aspirations of the community to children through the themes and behavior of the characters. Stories that are designed ostensibly for entertainment, aim at the same time to fulfill other more important goals. They are used as a mean of education that help in social control and uniformity with social values, in addition to the function of stories and folk tales in continued existence of the culture of that community. Stories are part of the so-called special literature (children literature), and occupy the forefront of this literature, because children tend to enjoy them and are attracted by the ideas and fantasies embedded in the actions and values of stories. Stories are of great value for their subsequent significant impact on the emotional and mental health as they represent a wide field to vent emotions and repressed desires. The unification of the child with protagonists of the stories may make him think about the solutions to the problems faced by following what was done by those figures, and leads him to cope logically with problems in reality than if he had not heard or read stories. Stories that characterize scientific curiosity as Al-Hiti (1998) says, keep the children's fantasies balanced, in addition to the folk tales that have no known author. Qasim (2013) refers to children stories as a useful educational tool; they enrich the child's experiences, develop skills and enhance positive attitudes. Stories can provide children with knowledge and information on facts about nature and life, thus enabling them of viewing different social environments, and enriching their language through developing their expressive abilities of thoughts, feelings and needs.

There are several types of stories; some are narrated by talking animals which children usually tend to like for the ease of reincarnation of animal roles, some are heroic stories that children try to simulate, others are fairy tales that draw the attention and cause control of feeling of the child, beside some other types like jinni, national, historical, religious, and also scientific stories. Children watching scenes of a story with great interest sharing the emotions with the characters, even involved in acting with them gives an evidence of the strong impact of the story on them. Never can the reader or listener to a story stay neutral from taking sides with characters and events, it is normal to imagine themselves in their shoes; agreeing, rejecting or admiring them, thus these characters should be implausible and familiar to the children, and this implies to all types of stories 
whether historical, realistic or representative that displays a model of human case in real life. However, fairy tales and demon stories that carry noble values develop imagination and fight evil and corruption. Inasmuch the previous review focused on the importance of culture in the life of society and its continuation, shaping of individuals, unfolding the importance of cultural diversity in human societies as an urgent need for the human race, it emphasized the importance of family in cultural transmission to children, intentionally and unintentionally, and the role of stories as one of the means adopted by the family in this culture transfer, whether audible or readable, the researchers have considered content analysis of children's stories that children between 8-12 years old tend to read.

All the above justified the present study as a new contribution in social, psychological and educational research. This study aims to understand the degree of existence of the values of cultural diversity in children's literature reflected by the characters, claiming that, to the knowledge of the researchers, no study has been conducted on the local and Arab World aiming at content analysis of children stories on cultural diversity values.

\section{Problem and Questions of the Study}

Because of the importance of cultural diversity values for human communities, they should be transmitted to children through different means, mainly, stories. This study aims at knowing to what level are these values embedded in children stories. The study raises the following questions:

1- What are the cultural diversity values embedded in Arabic children stories in Jordan for the age of 8-12 years?

2- What are the types of characters in children stories in terms of gender (male female), age (child-adult-old), and species (human-animal) that presented these values?

\section{Limits of the Study}

This study is limited to content analysis of the chosen stories tend to be read by $8-12$ years old children in Amman in 2015/2016. Generalization of the results is controlled by the sample of the study, and the instrument used with its psychometric properties of validity, reliability, and accuracy of reliable analysis of collected data.

\section{Significance of the Study}

This study gains its importance from the nature of the topic that aimed to find out how much are the cultural diversity values included in children literature (children's stories) in Jordan. It has been noticed that studies on this topic are rather rare, specially those related to the age group between 8-12 years, knowing that this age is a critical stage between middle and late childhood. This age group has its own psychological, mental 
and emotional characteristics, in addition to physical and biological, and should receive appropriate attention with respect to dedicated literature according to the needs of this group of the read, audible and visible literature. It is expected that this study might contribute in the research field of children stories, and pave the road for others to study the cultural diversity values in children stories, based on the findings of the current study.

\section{Definition of Terms}

\subsection{Culture}

Kluckhohn (1967) defines culture by giving several meanings to the concept such as being the total way of life of people, the social legacy the individual acquires from his group, and the way of thinking, feeling, and believing. He describes culture as a learned behavior, a precipitate of history, and a behavioral map, sieve, or matrix. Linton (1955) believes that what is meant by culture is intangible and impossible to be absorbed by direct perception. The form and content of cultures can only be drawn from the daily behavior arises from these cultures in various normal aspects of life. It also includes the products made by people in different professions and crafts. He views culture beyond the scope of the natural phenomena, and is discerned in comprehension of its physical, psychological and social effects in the life of people.

\subsection{Cultural Diversity}

Oxford Living Dictionary defines cultural diversity by "the existence of a variety of cultural or ethnic groups within a society". It refers to differences among people because of their racial or ethnic backgrounds, language, dress and traditions. UNESCO Universal Declaration on Cultural Diversity [PDF, 789 KB] in 2001 promotes the principle that "culture takes diverse forms across time and space. This diversity is embodied in the uniqueness and plurality of the identities of the groups and societies making up humankind. As a source of exchange, innovation and creativity, cultural diversity is as necessary for humankind as biodiversity is for nature. In this sense, it is the common heritage of humanity and should be recognized and affirmed for the benefit of present and future generations." The procedural definition of cultural diversity for the purpose of this study is the degree of occurrence and emphasis obtained by each value in the prepared classification.

\subsection{Children's Literature}

ynch-Brown and Tomlinson (2005) define children's literature as "a good quality trade books for children from birth to adolescence, covering topics of relevance and interests to children of those ages, through prose and poetry, fiction and nonfiction." (p. 3) It is a kind of literary art including different styles of prose and poetry that can influence children as good speech, whether it is verbal or written, and this term includes children stories, drama, and songs. It could also be defined as a set of artifacts that depict the thoughts, 
sensations, and fantasies of children in a multiple form of stories, drama, poetry, articles, songs, and press, based on moral and religious standards inseparable from the artistic common standards that reflect the human civilization. The procedural definition of children's literature for the purpose of the current study is the type of stories that children aged (8-12) years preferred to read among which a sample has been selected through the established criteria for this study.

\section{Review of Related Literature}

Children literature has gone through evolutionary stages over the past years according to the needs of societies. The story is, from the point of view of the child, a type of entertaining activity that doesn't cause boredom by recurrent; it brings quiet and calm feelings, causes outlet for blooming energies, provides training for imagination, mind, feelings and emotions, enables making social connections, and bridges for relations with others, in addition to indirectly teaching the child new vocabularies and expressions wouldn't be learned otherwise. Adults usually embed the tales and stories they tell some direct and indirect advices and moral exhortations in order to enhance the desirable behavior (Seddeek, 2010).

Following is a summary of the development in children stories since the eighteenth century. This literature used to have its own traditions of songs and tales revolving around recreation and entertainment, these songs were collected in what is called "Mobile Literature" (Zallat, 1994), carried by roving vendors from one place to another, forming later the corner stone for the children's "Blue Library". Among the most important French authors who played a prominent role in children's literature were La Fontaine, Fénelon, and Charles Perrault.

Authoring and translation movement widened in England; for example, "Cinderella", "The Sleeping Beauty", and "The Blue Bearded" were translated from French, and "One Thousand and Nights and One Nights" from Arabic. Daniel Defoe published "Robinson Crusoe" in (1719) followed by Jonathan Swift's "Gulliver's Travels" in (1726).

The United States has always been a pioneer in this field, children literature flourished in recent years, because it is the general outcome of other nations' literature augmented by use of modern means of communication. US excelled in the exploitation of capital, development of audio-visual aids, use of the latest achievements of education, psychology and industrial art, therefore apparent progress in the production of audio and video tapes broadcasted within the country and beyond. Instigated by the well-known writer of short stories Sara Cone Bryant, "story time" became part of the formal education at schools and children libraries. Young children sit around their teacher to listen to a story and discuss it. If was found that the pleasure of listening to a story is not less than reading it. Afterwards the idea of "colored library" appeared which includes several disciplines in drawings of children books and experts in output, implementation and 
casting industry. Based on this, we can say that US has a long tradition in children's literature and production of customized children books, not only what has been obtained from other civilizations. The broad development on the processes of production and creativity followed by the export of a great amount of produced children's literature became available in other countries. Some of the American authors interested in children's literature are Louisa May Alcott, Frank L. Tom, Eleanor Porter, Margaret Wise Brown, Randall Jarrell, and Maurice Sendak.

It has been noticed from the review of studies that analyzed children's literature content and stories in particular, American researchers paid more attention since the fifties of the last century to the stories and all the prose addressed to children, after which Arab researchers followed them lately. Some of these contributions have been reviewed as examples on the development of children literature in the United States, Europe, and the Arab World that focused on values in general.

Child, et.al. (1964) aimed at diagnosing the thought of achievement in the folk tales related to upbringing (4-6) cultures at the rate of 12 stories of each single culture. They adopted the method of stories analysis developed by Mcclelland (tat) for achievement motivation. The results indicated that there was a relationship between the achievement and patterns of societal upbringing, and that the value of tolerance positively correlated to achievement motivation reaching 50-49.

Brigges (1972) surveyed the favorite stories among kindergarten to the sixth elementary grade pupils at the United States through studying 2000 participants, revealing that the most favored stories were about animals and fairy tales. The study also involved cultural diversity in food and drink, and acceptance of the other among the fifth and sixth graders.

In his study, Dunphy (1972) analyzed characters, jobs, and how each character behaved in "King Arthur and the Knights of the Round Table", which revealed that there were several types of male characters who were good or evil to humanity in the atmosphere of the city of London. Another study by Hillman, (1974) who analyzed the roles of male and female characters in children's literature at the United States of America, which aimed at detecting changes in the gender roles from the sixties to the mid-seventies of the twentieth century in terms of accepting the behavior of the others, aggressive feeling towards the other sex, verbal empathy and care, competition and independence. The results showed that males outnumbered females at that time, and the males were far more aggressive than the females, who emphasized the qualities of sympathy, care, belonging, fantasy and sadness.

In (1975), D'Heurle et. al, conducted a comparative analytical study on 200 popular stories in the United States, Africa, Japan and Norway using a classification consisting of personality, gender, emotional content, results of behavior, aggressive behavior and direction content. Similarities and differences appeared among the studied cultures; 
American and Japanese stories were distinguished from the Norwegian and African stories in certain issues such as the value of courage, work, exploration and ambition that appeared clearly in the American and Japanese stories, while death appeared in the African stories then the Japanese. Walker and Lunz (1976) aimed to identify the impact of stories on stirring perceptions among children of different age, culture and race groups. No differences appeared between children's perception due to age, culture, gender, or race.

Al-Faisal (1981) identified the values in the stories in Syria by using 47 values from White's developed content analysis model on eight groups of stories addressed to children of 9-12 years. He found that the total values were (120) distributed according to White's domain into (42) of cultural knowledge values, (28) social values, (19) personality integration, and (17) patriotic and national values.

The study of Tommalieh (1988) that aimed to identify the story in children literature in Jordan through analyzing (13) story during the period (1976-1987), found that there was shortage in literature production addressed to children which has negative impact on children, and that the stories in general are rather rare in the Arab World. While the study of Al-Hayek (1995) found that the values in the Jordanian children stories included seven value groups in the (35) stories out of (140) stories in four children libraries, namely; religious, moral, social, eigenvalues, cognitive, economic, and aesthetic values, and that these values were not presented in a logical way that the authors failed in achieving the expected effectiveness.

Sawalha (2003) also conducted a study on the prevalence of values in the series of Little Sinbad Travels stories published by Dar Al-Mashriq in Amman in (1987). Content analysis was used in analyzing the sample that consisted of (14) stories about the archaeological and tourist sites and sites in Jordan, revealing that the stories included (1503) values distributed into (30\%) social values, ,(27\%) economic values, (22\%) patriotic and national values, and $(20 \%$ religious values. The researcher recommended that the authors should distribute these values in children stories in a lanced and logical order.

Values prevailing in the stories of the Palestinian writer Mustafa Harar were studied by Abu-Fanneh (2004). Five-fold rating of values was followed in analyzing values in (53) published stories in seven series between the period (1974-1996). Results showed that social values represented (36\%), human values $(23 \%)$, cognitive values $(11 \%)$, and patriotic values represented 6\%). Barakat (2010) also aimed to identify the availability of educational values in stories addressed to children aged (5-8) years in the series called Al-Basha'er Assagheera. Twelve stories about nature and environment surrounding the child in Syria were subject to content analysis on the term of using the sentence as unit of analysis according to the available values. Results revealed that the stories included 
(381) occurrence of values showing that the rate of repetition of values came as follows: first, cognitive and knowledge values, second, the spiritual and moral values, third, social, fourth, personal integration, fifth, recreational and aesthetic values, and finally, health and preventive values. The researcher recommended paying more attention and care about children stories for their important role in developing values in general.

The reviewed studies aimed to identify the stories addressed to children of different age groups in different parts of the world that study values in general. To the knowledge of the researchers of the current study, none of these studies showed interest in cultural diversity values, or concern of the "other" in the society in particular. The third millennium unfolded the failure of most societies in preparing generations capable of living in the modern global village of technological communication in acceptance of each other and social peace.

\section{Method}

Content analysis was used in this study to answer the questions. Scholars such as (Budd, 1967), (Blom, 1970), (Briggs, 1972), (Holsti, 1979) and (Kerlinger, 1986) define content analysis as a method of studying and analyzing communication in a systematic, objective, and quantitative manner for the purpose of measuring variables. In order to meet the objectivity, systematic and quantitative requirements, the research must have an identified content, a classification system, units of analysis, units of census, with clear rules of analysis and measuring reliability (Banks, 1971).

\subsection{Sample}

The following procedures were followed to choose the sample of the stories preferred by children aged (8-12):

- Children aged (8-12) both male and female and their parent were interviewed. The age of the children was identified taking into consideration that these children can choose the stories they like and read them by themselves.

- The number of the story books that this group tend to read, buy, and acquire was about (33) stories, according to the availability at the local bookshops or owned by the children themselves. (App. 1)

The sample of the study was selected by applying the rule of suitability based on excluding stories that do not carry a clear idea or depend on description such as describing an animal.

\subsection{Instrument}

Two instruments were used to collect data, the first one was a checklist, and the second one was the Classification of characters by (Child, Potter \& Levine, 1971). 


\subsubsection{Cultural diversity values' checklist}

The checklist was designed by the researchers including 28 values related to cultural diversity selected from the related literature of cultural diversity, and values obtained from Human Rights Organization on cultural diversity. The values are:

1. Foster of love and tolerance

2. Selfishness and loneliness

3. Feeling scared

4. Extremism

5. Intellectual and cultural genocide

6. Women's role in building cultures

7. Sense of the needs of others regardless of their affiliation

8. Mocking of a certain social class

9. Life gives opportunities to those who deserve

10. Accepting cultural diversity

11. Working partnership between cultures

12. Social cohesion

13. Rejection of racism and sectarianism among members of the same society

14. Achieving peace through peaceful dialogue between cultures

15. Blind obedience to community traditions

16. Reducing gap between cultures in the community

17. Calling for mercy and pardon

18. Gender discrimination against women

19. Promoting grassroots activities

20. Challenging ignorance and discrimination

21. Challenging intolerance and extremism

22. Unity of cultures to build the nation

23. Constructive dialogue between cultures

24. Dialogue between religions

25. Cultural diversity contributes to the intellectual civilized openness

26. Coexistence based on mutual respect

27. Right of citizens in homeland, regardless of religion, race, belief and sectarian 
28. Public and private partnership in education, communications, health, environment and tourism

7.2.2. Classification of (Child, Potter \& Levine, 1971) that identifies the following:

1- Types of stories: historical, religious, fairy tales.., and others.

2- The embodied characters in the story: main or secondary, human, animal, child, male or female.

3- Social class: rich, middle or poor.

4- Type of enhancement or punishment.

This classification of characters for this study is limited to gender (male and female), age (young and old) and type (human and animal).

\subsection{Units of Analysis}

Units of analysis were as follows:

1- Theme: to analyze the stories according to the cultural diversity values classification developed for this study, the "theme" was used as it occurred as a "word", a "sentence" a paragraph, or a picture whether a symbol or a drawing.

2- Character: used according to Child, Potter and Levin classification. Character refers to the doer whether a human, animal, or an object that acts within the story events as a main or secondary actor.

\subsection{Data analysis}

Data was analyzed by frequency of occurrence of the each value and character.

\subsection{Reliability}

To assure reliability, two methods were adopted

1- Five stories making $20 \%$ of the stories were randomly chosen and given to an external analyst after being trained to use the checklist, the ratio of agreement between the researchers and the external analyst revealed (0.79) on Scott Coefficient of Agreement which is acceptable for content analysis (Ober, 1971).

2- To find the consistency coefficient, the researchers analyzed and re-analyzed five stories with the interval period of fifteen days, the result was (0.93).

\subsection{Validity}

To assure validity, a group of specialists interested in children's rights and cultural diversity were asked to judge the list of the cultural diversity values, they approved the 
list and pictures after excluding some of which didn't carry a clear idea related to the theme of the paper.

\section{Findings and Discussion}

Collected data was analyzed using frequencies and percentages of cultural diversity values that counted (258) themes in (33) stories in order to answer the questions of the study. Findings related to the first question: - What are the cultural diversity values embedded in children stories for the age of 8-12 years? Table (1) shows the frequencies and percentages of occurrence of the cultural diversity values in children stories presented in a descending order.

Table (1)

Frequencies and percentages of cultural diversity values occurrence in a descending order

\begin{tabular}{|c|c|c|c|}
\hline No. & Values & $\begin{array}{l}\text { frequenc } \\
y\end{array}$ & $\%$ \\
\hline 1 & $\begin{array}{l}\text { foster of love } \\
\text { and tolerance }\end{array}$ & 34 & $\begin{array}{c}13 . \\
1\end{array}$ \\
\hline 2 & $\begin{array}{l}\text { Selfishness and } \\
\text { loneliness }\end{array}$ & 32 & $\begin{array}{c}12 . \\
4\end{array}$ \\
\hline 3 & Feeling scared & 24 & 9.3 \\
\hline 4 & Extremism & 20 & 7.7 \\
\hline 5 & $\begin{array}{l}\text { intellectual and } \\
\text { cultural } \\
\text { genocide }\end{array}$ & 16 & 6.2 \\
\hline 6 & $\begin{array}{l}\text { women's role in } \\
\text { building cultures }\end{array}$ & 14 & 5.4 \\
\hline 7 & $\begin{array}{l}\text { sense of the } \\
\text { needs of others } \\
\text { regardless of } \\
\text { their affiliation }\end{array}$ & 14 & 5.4 \\
\hline 8 & $\begin{array}{l}\text { mocking of a } \\
\text { certain social } \\
\text { class }\end{array}$ & 12 & 4.6 \\
\hline 9 & $\begin{array}{l}\text { life gives } \\
\text { opportunities to } \\
\text { those who } \\
\text { deserve }\end{array}$ & 12 & 4.6 \\
\hline 10 & $\begin{array}{l}\text { accepting } \\
\text { cultural diversity }\end{array}$ & 8 & 3.1 \\
\hline 11 & $\begin{array}{l}\text { working } \\
\text { partnership } \\
\text { between } \\
\text { cultures } \\
\end{array}$ & 8 & 3.1 \\
\hline 12 & social cohesion & 8 & 3.1 \\
\hline 13 & $\begin{array}{l}\text { rejection of } \\
\text { racism and } \\
\text { sectarianism }\end{array}$ & 8 & 3.1 \\
\hline
\end{tabular}




\begin{tabular}{|c|c|c|c|}
\hline & $\begin{array}{l}\text { among } \\
\text { members of the } \\
\text { same society }\end{array}$ & & \\
\hline 14 & $\begin{array}{l}\text { achieving peace } \\
\text { through } \\
\text { peaceful } \\
\text { dialogue } \\
\text { between } \\
\text { cultures }\end{array}$ & 8 & 3.1 \\
\hline 15 & $\begin{array}{l}\text { blind obedience } \\
\text { to community } \\
\text { traditions }\end{array}$ & 8 & 3.1 \\
\hline 16 & $\begin{array}{l}\text { reducing gap } \\
\text { between } \\
\text { cultures in the } \\
\text { community }\end{array}$ & 6 & 2.3 \\
\hline 17 & $\begin{array}{l}\text { calling for mercy } \\
\text { and pardon }\end{array}$ & 6 & 2.3 \\
\hline 18 & $\begin{array}{l}\text { gender } \\
\text { discrimination } \\
\text { against women }\end{array}$ & 4 & 1.5 \\
\hline 19 & $\begin{array}{l}\text { promoting } \\
\text { grassroots } \\
\text { activities }\end{array}$ & 4 & 1.5 \\
\hline 20 & $\begin{array}{l}\text { challenging } \\
\text { ignorance and } \\
\text { discrimination }\end{array}$ & 2 & 0.7 \\
\hline 21 & $\begin{array}{l}\text { challenging } \\
\text { intolerance and } \\
\text { extremism }\end{array}$ & 2 & 0.7 \\
\hline 22 & $\begin{array}{l}\text { unity of cultures } \\
\text { to build the } \\
\text { nation }\end{array}$ & 2 & 0.7 \\
\hline 23 & $\begin{array}{l}\text { constructive } \\
\text { dialogue } \\
\text { between } \\
\text { cultures }\end{array}$ & 0 & 0 \\
\hline 24 & $\begin{array}{l}\text { dialogue } \\
\text { between } \\
\text { religions }\end{array}$ & 0 & 0 \\
\hline 25 & $\begin{array}{l}\text { cultural diversity } \\
\text { contributes to } \\
\text { the intellectual } \\
\text { civilized } \\
\text { openness }\end{array}$ & 0 & 0 \\
\hline 26 & $\begin{array}{l}\text { coexistence } \\
\text { based on mutual } \\
\text { respect }\end{array}$ & 0 & 0 \\
\hline 27 & $\begin{array}{l}\text { right of citizens } \\
\text { in homeland, } \\
\text { regardless of }\end{array}$ & 0 & 0 \\
\hline
\end{tabular}




\begin{tabular}{|c|l|c|c|}
\hline & $\begin{array}{l}\text { religion, race, } \\
\text { belief and } \\
\text { sectarian }\end{array}$ & & \\
\hline 28 & $\begin{array}{l}\text { public and } \\
\text { private } \\
\text { partnership in } \\
\text { education, } \\
\text { communications } \\
\text {, health, } \\
\text { environment } \\
\text { and tourism }\end{array}$ & & 0 \\
\hline
\end{tabular}

Some values appeared more frequently than others such as item No. (1) stating "Fostering a spirit of love, tolerance and assistance" appearing (34) times with the percentage of (\%13.1), followed by item No. (2) about "Selfishness and loneliness" occurring (32) times with the percentage of (\%12.4), and item No. (3) about "Fear" repeated (24) times with the percentage of (\%9.3), then comes item No. (4) on "Extremism" that appeared (20) times with the percentage of (\%7.7) followed by item No. (5) on "Intellectual and cultural genocide" with the frequency of (16) and a percentage of (\%6.2). The rest of items frequency of appearance varied from (14) going down to (2) times. Six values were absent from these stories; items (23), (24), (25), (26), (27) and (28).

Table No. (2) illustrates the findings related to the second question: What are the types of characters in children stories in terms of gender (male - female), age (young-old), and types (human-animal)?

Table No. (2)

Frequencies and percentages of occurrence of the main characters

\begin{tabular}{|l|l|c|c|}
\hline \multicolumn{2}{|c|}{ Types of characters } & \multicolumn{2}{|c|}{$\begin{array}{c}\text { Frequency \& } \\
\text { percentage of } \\
\text { occurrence }\end{array}$} \\
\hline \multirow{2}{*}{ gender } & Male & 34 & $9.9 \%$ \\
\cline { 2 - 4 } & Female & 40 & $11.6 \%$ \\
\hline \multirow{2}{*}{ Age } & Young & 30 & $8.7 \%$ \\
\cline { 2 - 4 } & Old & 46 & $13.4 \%$ \\
\hline \multirow{2}{*}{ Type } & Human & 150 & $43.6 \%$ \\
\cline { 2 - 4 } & Animal & 44 & $12.8 \%$ \\
\hline \multicolumn{2}{|c|}{ Total } & 344 & $100 \%$ \\
\hline
\end{tabular}

Analysis of data according to Child, Potter and Levine revealed that female protagonist characters appeared more than the male characters in the children stories studies $(11.6 \%-9.9 \%)$, the elderly characters appeared more than the young characters $(13.4 \%$ 
- 8.7\%), and the human characters appeared far more than the animal characters $(43.6 \%$ $-12.8 \%)$.

Cultural diversity values appeared in the studied children stories in a very poor way that couldn't reflect the importance of them. This showed that writing children stories was not a deliberate and carefully thought out process, but without considering the context and its effect on the readers specially children. Several reasons stand behind this result such as; most of these stories were taken from societies other than the Arabic in general and the Jordanian in specific. Writers of children stories have no or little knowledge about the nature of the child's growth, his needs and the mental processes, and the emotional and social aspects specially during the early years of childhood when they unite with the characters of the stories and absorb the values and unleash their fantasies. Unless the stories are intentionally educational and positively directed, their impact will have negative impact despite the fun and pleasure they provide.

To conclude the discussion, the researchers did not find suitable amount of cultural diversity values in the studied children stories commensurate with the Jordanian society values, and the occurrence of the values was not logically distributed in accordance with the educational and social objectives of children literature. As the components of the story such as the idea, the theme, the style, the imagination and language, affect the child formation, it is of great importance to employ and benefit from it at home and school, by carefully selecting the best of it and knowing how to display them to the child. Mothers, educators and teachers are responsible of telling stories to children at early childhood specially at KGs as they are not able to read yet. Story telling has its own taste of charming expression that increases its artistic value and infuses life into it grabbing the child's attention. Children story writers should take into account precision and honesty without contradicting with self, rules of science and language, commitment to values and nationalism, respect to beneficial traditions and customs, and draw from the past in order to embrace future. Building the value system during childhood is the basis for a balanced individual personality, in a harmonious and safe society with its different cultural categories.

\section{Recommendations}

Based on the findings of the study, following are some recommendations:

1- Jordanian and Arab writers should consider writing children literature in a renewed cultural value structure, thinking of culture as a complex mental component in the hearts, minds and senses of children.

2- Parents, care takers and educational institutions should review the stories they provide their children with, and provide them with stories that contain the elements of mental health, love of others, tolerance and respect, and other values that the community wants to instill in their children. 
3- Researchers could conduct similar studies on children's literature of all its types; poems, narrative, drama and journals to identify strengths and weaknesses in order to avoid all the negatives that conflict with the promotion and dissemination of the values of cultural diversity in human society.

\section{Appendix 1}

\section{The Sample of the Study}

\section{The Chosen Children Stories}

$$
\begin{aligned}
& \text { 1. الحمامه المطوقه }
\end{aligned}
$$

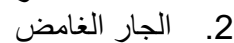

$$
\begin{aligned}
& \text { 3. سر البطه البيضاء البغاء } \\
& \text { 4. . الصائغ و الافعى اليضى } \\
& \text { 5. السبع في محنه }
\end{aligned}
$$

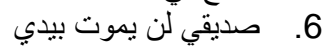

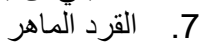

$$
\begin{aligned}
& \text { 8. عندما تتكلم الاشجار } \\
& \text { 9. }
\end{aligned}
$$

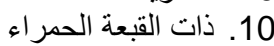

$$
\begin{aligned}
& \text { 11. الحسناء النائمة الفعة الحماء } \\
& \text { 12. ذات الخصلة الذ1 هبية و الدببة الثناثة }
\end{aligned}
$$

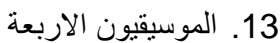

$$
\begin{aligned}
& \text { 14. 13. بيضاء التلجون الاقزئن الاربعة السبعة } \\
& \text { 15. الحسناء و الوحش التش } \\
& \text { 16. هانسل و غريتل } \\
& \text { 17 } \\
& \text { 18. العنزات الثناثاء } \\
& \text { 19. فرخ البط العجيب } \\
& \text { 20. بوسيت الصغيرة } \\
& \text { 21. القطو الحذاء } \\
& \text { 22. 21. جندي الرصاص الصنغ الصغير } \\
& \text { 23. عقله الاصيع الرصاص } \\
& \text { 24. الحديقة السرية } \\
& \text { 25. فطنة طباخ الحنة } \\
& \text { 26. 26 العمل كنز } \\
& \text { 27. من زر العل حكند } \\
& \text { 28. ذكاء فلاحه } \\
& \text { 29. اين ياسمين } \\
& \text { 30 30 ثيلينا }
\end{aligned}
$$

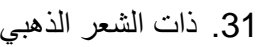

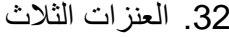

$$
\begin{aligned}
& \text { 33. اوليفرتويست العزت }
\end{aligned}
$$




\section{References}

\subsection{English References}

Allport W, (1983). Pattern and Growth in Personality, Holt, London.

Banks, James A. (1971). A Content Analysis of the Black American in Textbooks, in Banks, James \& William W. Joyee (eds). Teaching social studies to culturally different children, Addison-Wesley, Mass.

Blom, Gastom E. \& Others. (1970). A Motivational Content Analysis of Children's Primers, in Levin, Harry \& Joanna P. Williams (eds) Basic Studies on Reading, Basic Books, New York.

Briggs, N., (1972). A Survey of Favorite Stories of Pupils from Kindergarten to Grade Six, The Speech Teacher, 21 (2).

Budd, Richard W. \& Others, (1967). Content Analysis of Communications. New York: MacMillan.

Child, Irvin L. \& Others, (1964) Achievement Themes in Folk Tales Related to Socialization Practice, in Atkinson, John W. (eds), Motives in Fantasy, Action and Society. Princeton, N.J.: Van Nostrand.

Child, Potter \& Levine (1971). Children textbooks and Personality Development, in Thompson, George, \& Others, (eds), Social Development and Personality, New York: Wiley.

D'Heurle, Adam \& Others, (1975). World View of Folktales A Comparative Study, The Elementary School Journal, 76 (2).

Dunphy, Dexter C., (1972). King Arthur and The Knights of the Round Table, in Dunphy Dexter C. (ed). The Primary Group. New York: Apple Century.

Hillman, Judith Stevenson, (1974). An Analysis of Male and Female Roles in Two Periods of Children's Literature, Journal of Educational Research, 68 (2) pp

Holsti, Ole R., (1969), Content Analysis for Social Sciences and Humanities, New York: Addison-Wesley.

Kerlinger, Fred N., (1986). Foundations of Behavioral Research, $3^{\text {rd }}$ Ed, New York: Holt, Rinehart and Winiston.

Kluckhohn, C., \& Henry Murray, (1967). Personality: The Determinants, in Clyde Kluckhohn, \& Henry Murray (eds). Personality, Nature, Society and Culture, $2^{\text {nd }}$ Ed. New York: Alfred A. Knoff. 
Lynch-Brown, C. \& TLomlinson, C. (2005). Essentials of Children's Literature, 5th edition. New York: Pearson.

Ober, Richard L. et al., (1971). Systematic Observation of Teaching, New Jersey: Prentice-Hall.

Pervin, Lawrence A., (1990). Personality: Theory Assessment and Research, New York: John Wiley.

Linton, Ralph, (1955), The Tree of Culture, New York: Vintage Books.

Salvin, Robert, (2009). Educational Psychology: Theory and Practice, 5th Edition, New York: Pearson.

Walker, V., \& Mary Lunz , (1976), Symbols, Fairytales and School-age Children, The Elementary School Journal, November.

UNESCO Universal Declaration on Cultural Diversity, 2 November 2001.

http://portal.unesco.org/en/ev.php-URL ID=13179\&URL DO=DO TOPIC\&URL SECTION=201.htmI

\subsection{Arabic References}

Al-Ajeely, S., (1979) An Analytical Study of Mother's Stories. Unpublished MA Thesis at Ibin Rushd College in Baghdad.

Al-Faisal, S. R., (1998). The Technical Format of Children' Story in Syria. Al-Mawqif Al-Adabi Journal, 208, 107-108.

Al-Hadidi, A., (2010). In Children's Literature. Cairo: Egyptian Anglo Library.

Al-Hayek, A. (1990). Values in Jordanian Children's Literature.

Al-Hiti, H. N. (1998). Children's Culture. Alam Al-Marifa. 23, p. 94.

Abu-Fanneh, M. (2004). Values in Jordanian Children Stories.

Barakat, F. S., (2010). The extent of Values Availability in a Sample of Children Stories in Syria. Majallet Jamiat Dimashq. (3). 26.

Qasim, A. I. (2013). Children Stories: Elements, Types and the Most Prominent Features. 
Sawalha, M., (2003). An Analytical Study of Values in a Sample of Children Stories.

Siddeek, N., (2010). Children Stories. Cairo: Arab Book Development Center, Egyptian General Book Organization.

Tommalieh, F., (1988). Story in Children's Literature in Jordan from 1976-1987.

Zalat, A., (1994). Children's Literature: Origins, concepts, and Traditional Visions. $4^{\text {th }}$ Ed. Cairo: Arab Company for Publishing and Distribution. 